\title{
Motivating Learners and the Importance of Materials Used in Language Teaching
}

\author{
Akbar Azarkamand ${ }^{1}$, Mahboobeh Roshanak ${ }^{2}$, Mohsen Fatehi ${ }^{3, *}$ \\ ${ }^{1}$ Birjand University, English Department, Birjand, Iran \\ ${ }^{2}$ Islamic Azad University, Mashhad Branch, Mashhad, Iran \\ ${ }^{3}$ Imam Reza International University, English Department, Mashhad, Iran
}

*E-mail address: Fatehi4156@gmail.com

Keywords: language learning, teaching material, motivation

\section{ABSTRACT}

The motivation of the learner is one of the most important acto in Seco l Language Acquisition (SLA), meanwhile language teaching materials are ho ing a ver, rpor ant effect and role in language learning and teaching activities. This researc 1 on how ifferent materials motivate students. Many factors which affect student's moti at on to ts teaching materials were perceived, such as interest in the subject matter, level of d incturty, releva
perception of usefulness.

\section{INTRODUCTION}

Virtually all students are motivated in ne another. One student may be keenly interested in classroom subject matter and seek o challe, ging course work, participate actively in class discussions, and earn high 0 on ass oned projects. Another student may be more concerned with the social side of sc bol, inte acting with classmates frequently, attending extracurricular activities almo erhaps running for a student government office. Still another may be focu ed on at ics, excelling in physical education classes, playing or watching sports most afte $\mathrm{h}$ and we $\mathrm{de}$, and faithfully following a physical fitness regimen. Yet another student - p haps ause of an undetected learning disability, a shy temperament, or a seemingly uncoord atud body- be motivated to avoid academics, social situations, or athletic activities. Motiv tion ds to inc eased effort and energy. Motivation increases the amount of effort and encrg. ha learn s expend in activities directly related to their needs and goals. It determines whethe ey pu sue a task enthusiastically and wholeheartedly or apathetically and lackadai ica Moti increases initiation of and persistence in activities. Learners are more likely begi a task they actually want to do. They are also more likely to continue working at it until the ed it, even if they are occasionally interrupted or frustrated in the process (Larson, 20 Maehr, 1984; Wigfield, 1994). In general, then, motivation increases students' time on task, an mportant factor affecting their learning and achievement. it affects cognitive processes and affects what learners pay attention to and how effectively they process it (Eccles \& Wigfield, 1985; Pintrich \& Schunk, 2002; Pugh \& Bergin, 2006). For instance, motivated learners often make a concerted effort to truly understand classroom material — to learn it meaningfullyand consider how they might use it in their own lives. It also determines which consequences are reinforcing and punishing. The more learners are motivated to achieve academic success, the more they will be proud of an A and upset by a low grade. The more learners want to be accepted and respected by peers, the more they will value membership in the "in" group and be distressed by the ridicule of classmates. Motivation often enhances performance. Because of the other effects just identified-goal-directed behavior, effort and energy, initiation and persistence, cognitive processing, and the impact of consequences - motivation often leads to improved performance. As 
you might guess, then, students who are most motivated to learn and excel in classroom activities tend to be our highest achievers (A. E. Gottfried, 1990; Schiefele, Krapp, \& Winteler, 1992; Walberg \& Uguroglu, 1980). Conversely, students who have little interest in academic achievement are at high risk for dropping out before they graduate from high school (Hardré \& Reeve, 2003; Hymel et al., 1996; Vallerand, Fortier, \& Guay, 1997).

Success in Second Language Acquisition (SLA) depends on a variety of factors such as the amount of exposure to the natural target language practice, the duration and intensity of the language course, and last but not least, the characteristics of the language learner. Motivation-one element of the learner characteristics is one of the most important factors in the field. Cohen and Dörnyei (2002) contended that motivation is the key learner variable and nothing much happens without it. It determines the degree of effort learners put into foreign or second language learnin The more motivation they may have, the more effort they tend to put into learning the langy age. Th fore, teachers' biggest concern is always whether students are well motivated and wi to learn hat they teach. According to Wachob (2006), teaching materials undergird the construc motiv lon. Seven and Engin (2007) also stressed, language teaching materials are baving a vo imr ortant effect and role in language learning and teaching activities. It showed at mo vation an come from teaching materials. Therefore, since no research can cover the the censive hotivational variables this paper tried to focus on how different materials motiy e studen.

\section{THEORETICAL SUBSTRUCTURE}

The last four decades have witnessed a considerab amount of res ch that investigates the nature and role of motivation in SLA process. Gardner $z$ Lambert (1972) pioneered on motivation, proposing an integrative-instrumental duality, which $\mathrm{b}$ ame widel accepted and confirmed by a number of studies. Their ten-year-long research prog in $w^{1}$ ch they found that success in language attainment was dependent on learn affective wuetions toward the target linguisticcultural group, gave validity to the study of mot ratu CI A.

Some studies have attempted to extend Gardne s const act by adding new components, such as intrinsic/extrinsic motivation, intelle curiosit attribution about past successes/failures, need for achievement, self-confidence nd of er situat 1 -specific variables such as classroom events and tasks, classroom climate a d course content and teaching materials, teacher feedback, and grades and re aras. In 1980 s the learning situation itself received more attention and three sets of motiva compono were identified by Dornyei (1994): i) course-specific motivational compon $\mathrm{ts}$; teacher-specific motivational components; iii) group-specific motivational compents. The co specific motivational components relate to the class syllabus, the materials us d, the teaching nethod, and the learning task. Dornyei uses the conditions presented by Ko (18 83) a d later by Crookes and Schmidt (1991) to describe these conditions: Interest, Relevance, pectar $y$, and Satisfaction.

The firs can ory, in , is related to intrinsic motivation and is centred on the individual's inher curig ity and csire to know more about him or herself and his or her environment. The second, a prerequisite for "sustained motivation and requires the learner to perceive that impor wersonal needs are being met by the learning situation" (Keller, 1983: 406). It refers to the extent $t$ which the student feels that the instruction is connected to important personal needs, values, or goáls. At a macrolevel, this component coincides with instrumentality; at the level of the learning situation, it refers to the extent to which the classroom instruction and course content are seen to be conductive to achieving the goal, that is, to mastering the L2. Expectancy refers to the perceived likelihood of success and is related to the learner's self-confidence and self-efficacy at a general level; at the level of the learning situation, it concerns perceived material difficulty, the amount of effort required, the amount of available assistance and guidance, the teacher's presentation of the material, and familiarity with the task type. Satisfaction concerns the outcome of an activity, referring to the combination of extrinsic rewards such as enjoyment and pride. There is that determinant of motivation which is perhaps the most traditional: reward, punishment or outcomes. Activities for which the motivating forces are outcomes have been referred to as 
extrinsically motivated, as opposed to those which are intrinsically motivated (Deci, 1975). This framework appears to be particularly useful in describing course-specific motives. Thus my research will be based on Dornyei's motivation construct to explore through what ways teaching materials affect students' enthusiasm of language learning.

\subsection{ANALYSIS AND DISCUSSION}

Guariento \& Morley (2001) stated that extracting real information from a real text in a new/different language can be extremely motivating, therefore increasing students' motivation for learning by exposing them to 'real' language. In addition, authentic materials also give the reader the opportunity to gain real information and know what is going on in the world around them. Authentic texts can be motivating because they are proof that the language is used frreal-life purposes by real people (Nuttall, 1996). Thus,

Nowadays there are recommendations that the language presented should be auth ic (Widdo on, 1990). Nuttall (1996) gives three main criteria when choosing texts to be yed in class om suitability of content, exploitability and readability. Suitability of con nt means $r$ ading material should interest the students as well as be relevant to their nee Exp tabilit efers to how the text can be used to develop the students' competence as re der text th can not be exploited for teaching purposes has no use in the classroom. Re dability $\mathrm{red}+0$ describe the combination of structural and lexical difficulty of a text, as we $\mathrm{w}^{\mathrm{y}}$ ferring to amount of new vocabulary and any new grammatical forms present.

Kawai (2000) pointed out, from a constructivist perspecti e, coutent relo of learning materials to the learner's existing knowledge is a key ingredie for intrinsic motivation. Deci and Ryan (1985) create the construct of intrinsic and extrin motivatio theory. Intrinsic motivation concerns behavior performed for its own sake in order experienc pleasure and satisfaction such as the joy of doing a particular activity or satis fuing one's 4 . It is a state where the relevance for the learner of the content of the material is t reason for learning.

As Brozo (2005) concluded in order to foster intris stivation, teacher should try to create learning activities that are relevant to atydents' li es. One of effective strategies is connecting the subject with your students' culture, utsic interest or social lives.

As Crookes and Schmidt (1991, inte out a program which appears to meet the students' own expressed needs will be more ...tiv. o, mom dfficient, and thus more successful. Cunningsworth (1984) also stressed that materials ould meet students' needs: "Students particularly more sophisticated adults ne a th that to materials from which they are learning have to be connected with the re world a the same time they must be related positively to the aspects of their inner make $y$ such as age, lo 1 of education, social attitudes, the intellectual ability and level of emotional m rity."

\section{CONC YON}

er tried 0 induce the importance and effects of teaching materials in language learning. saffect student's motivation towards teaching materials: interest in the subject matter, lev difficulty, relevance to existing knowledge, perception of usefulness. These findings are consistent ith motivation construct identified by Dornyei (1994). Reviewed above, the level of difficulty will be a good determinant of selective learner attention. What's more, personal relevance makes an enormous difference in students' attitudes toward learning. Finally, visual material and authentic material will arouse students' interest and enthusiasm. 


\section{REFERENCES}

[1] Brozo, W.G. (2005). Connecting with students who are disinterested and inexperienced. Thinking Classroom Vol. 6, Issue. 3, p. 42

[2] Cohen, A.D. and Dörnyei, Z. (2002). Focus on the Language Learner: Motivation, Styles and Strategies. An Introduction to Applied Linguistics. Schmitt, N. (Ed.). London: Arnold.

[3] Crookes, G., \& Schmidt, R. W. (1991). Motivation: reopening the research agenda. Language Learning, 41/4, 469-512. [4] Cunningsworth, A. (1984). Evaluating and selecting EFL teaching materials. New York: Teachers College Pres.

[5] Deci, E. L. (1975). Intrinsic motivation. New York: Plenum.

[6] Deci, E. L. and Ryan, R. M. (1985). Intrinsic Motivation and Self Deterp. tion in H han Behavior. New York: Plenum Press.

[7] Dornyei, Z. (1994). Motivation and motivating in the foreign lan age ossroo Modern Language Journal, vol 78:273-284.

[8] Dornyei, Z. (2007). Research Methods in Applied Linguistics. $/$ ford Un sity ress.

[9] Gardner, R.C. \& Lambert, W. (1972). Attitudes and Moti tion Second I anguage Learning. Rowley, MA: Newbury House.

[10] Guariento, W. \& Morley, J. (2001). Text and Task uthenticity in the EFL Classroom.

[11] Kawai, Y. (2000). Effects of cultural contextualiza on in listen fig materials on motivation and strategy use.

[12] Keller, John M. (1983). Motivational Des Instruction. Instructional Design Theories and Models: An Overview of their Current St us. M. Reigelruth. Hillsdale, NJ: Lawrence Erlbaum.

[13] Nuttall, C. (1996). Teaching Read g Skills ing a foreign language (New Edition). Oxford, Heinemann.

[14] Peacock, M. (1997). T e Effect uthentic Materials on the Motivation of EFL Learners in English.

[15] Robson, C. $(10)$, Real research: A resource for social scientists and practitioner researchers slack vell. Oxfó

[16] Seven, M. S Jigm, (2007). The Importance and Effect of Using Aid Materials in Foreion Lang e Tearing.

[17] W rlace, (1992), eading. Oxford University Press.

[18] Wâ o). Methods and materials for motivation and learner autonomy Reflections.

[19] Widdo n/H.G. (1990). Aspects of Language Teaching. Oxford, O.U.P. 